\title{
THE RELATIONSHIPS SETTING BETWEEN EVALUATION ACTIONS THE AND STYLES OF DIDACTIC TRANSPORT AT TEACHERS OF PHYSICAL EDUCATION
}

\author{
Radosław Muszkieta $^{1}$, Marek Napierała ${ }^{2}$, Walery Zukow ${ }^{1}$, Mirosława Cieślicka ${ }^{2}$, \\ Sergii Iermakov ${ }^{3}$, Zhaneta Kozina ${ }^{3}$ \\ ${ }^{1}$ Faculty of Earth Sciences, Nicolaus Copernicus University, Torun', Poland \\ ${ }^{2}$ Faculty of Physical Education, Health and Tourism, Kazimierz Wielki University, Bydgoszcz, \\ Poland \\ ${ }^{3}$ Faculty of Physical Education and Sport, National Pedagogical University, Kharkiv, Ukraine
}

Original scientific paper

UDC: 796.015 .367

\author{
Corresponding author \\ Walery Zukow, E-mail: w.zukow@wp.pl, \\ Faculty of Earth Sciences, Nicolaus Copernicus University, Torun, Poland
}

Keywords: styles of didactic communication, teacher, physical education, actions controlestimating.

\begin{abstract}
Introduction. Question of estimating the pupils' achievements was one should to the hottest discussed in present didactics. Is the control and estimating the pupil it once of the teacher's the most difficult actions in process of teaching and learning, in this also with physical education. The superior task resting on teacher this qualification of aims of control and opinion as well as reliable and unambiguous criterions. In paper is presented styles it is possible communicating to accept that the most desirable and positive instrumental style is on the job teacher's professional, in this the teacher of physical education also.

Aim. It was the aim of work the qualification of relationships setting between chosen components estimating the pupils' achievements and the represented by studied teachers of physical education styles of didactic transport.

Material and method. It investigations were subjected was the teachers of physical education (woman $-\mathrm{N}=282$; men $-\mathrm{N}=298$ ) with professional full qualifications working at elementary schools, secondary-school and secondary in Poznań $(\mathrm{N}=204)$, Wrocław $(\mathrm{N}=171)$ and Łódź $(\mathrm{N}=205)$. It totality was has given an examination was 580 teachers.

Results. It the conducted analysis of results of investigations on the ground was affirmed was that the of didactic transport represented by teachers of physical education style has on chosen components of action multiple influence control - estimating.

Conclusions. Teachers, regardless of the subject represented and the style of communication, should take into account emotional, intellectual and physical predispositions in assessing students' achievements. The surveyed physical education teachers mainly take into account physical predispositions, unfortunately they are much less likely to take into account in assessing the emotional and intellectual state of pupils.
\end{abstract}




\section{Introduction}

The issue of assessing student achievement is one of the most fervently debated in contemporary teaching. In authoritarian systems overestimate the role of educational assessment and abusing it, using the transmission of information about the achievements and often - a lack of student achievement, to improve the teacher's authority and increase its power. In the humanities teaching systems broadens the scope to assess the achievements' assessment of the whole student as an indivisible and original form, yet refuses to standardization requirements, which could locate the school, rather bureaucratic institution above a lively and sensitive young man (Niemierko 1999).

Monitoring and evaluation of the student is one of the most difficult tasks a teacher in the process of teaching and learning, including physical education. An important role in assessing the proper plays to develop appropriate criteria for the evaluation and control of the student. How to determine the criteria, which take into account - while complying with the disposition Ministry of Education, which says: "In determining the degree of physical education - if he is not the subject of code - should in particular take into account the efforts made by the student in the fulfillment of duties arising from the specific nature of the subject". The overriding task of the teacher is incumbent on the objectives and the monitoring and evaluation of reliable and unambiguous criteria (Muszkieta 2004, 2005).

Osiński (1994) concludes that "assessment should primarily include personality criteria, expressed in systematic work on oneself and one's body. The adoption of such a variant would not mean at all a relaxation of the student's requirements or excessive liberalism, on the contrary, it could be an element that would definitely discipline and order the students' actions and would point to the sense of their persistent, rational self-development. The assessment thus issued should be supplemented with the general characteristics of the student, which would include both important information on the current physical condition (body structure and posture, movement skills, level of physical fitness, etc.), as well as the current needs of the student. Such characteristics would serve both the student, the teacher and the parents. School assessment should be used for a more complete introduction of the student into the world of physical and health education. In this sense, it should always be a signpost that shows the student how far he or she has approached the goal and whether it even follows the right path. But the assessment must also be an encouragement and even encouragement for further systematic work on yourself. It should become a pretext to teach how to shape your body, improve your health and how to live in physical culture. This is demanded both by the process of shaping a conscious attitude of the physical educator to the effects of his work, as well as the need to take into account and display the elements of self-control and self-assessment" (Osiński 1994).

Strzyżewski (1996) stated that "physical education involves shaping both the humanistic values of the student and the biological features of his organism". That is why a physical education teacher must use in his work equally from both branches of knowledge about a human being: from the humanities and biological sciences. The primary school teacher (first and second stage of education) in addition to the above-mentioned sciences must also use exact sciences (eg mathematics) and artistic sciences (eg art, music, technology). The teacher must be able to choose the most important features of the student and the most appropriate control methods to assess. In the opinion of the teacher should be able to get the optimum, and not the maximum of information about the results achieved, in order to be able to compare them with the assumed functions (Strzyżewski 1996). Other contemporary studies emphasize the need to select appropriate tests for pedagogical control of youth physical activity (Bodnar, Andres, 2016, Koryahin, Blavt, 2016) and adaptation (adaptation) to physical activity (Abzalilov, Rybakov, Isaev, Erlikh, 2017; Zerf, 2017).

Świętochowski (1994) distinguished three styles of didactic communication: self-center, self-centered and instrumental (moderate).

The allocentric style is characterized by a teacher who in communication concentrates on the recipient - partner. He easily succumbs to persuasion and suggestions of the interlocutor, he listens 
more willingly than he says. It adapts its answers to the needs of the recipient. He often asks other people for advice and he listens to them willingly. Demands feedback from the conversation partner.

The egocentric style is represented by the teacher, whose messages are focused on him. Rather, it does not take into account another, beyond its own, cognitive and emotional perspective. He rarely listens to a partner, does not allow him to speak, is an advocate of bans and orders. It is up to him to determine the start and end of the conversation, at the same time directing its course.

The instrumental style (moderate) is characterized by a teacher who listens carefully to his conversation partner, exchanges views on both sides. He wants to agree positions, he compromises. The goal of communication between partners, ie teacher and pupil, teacher and teacher as well as teacher and parent, is the desire to acquire the necessary information. He tries to help his partners communicate in solving tasks and problems.

In the presented communication styles, it can be assumed that the instrumental style of the teacher's professional work, including the physical education teacher, is the most desired and positive. Teachers characterized by the remaining styles of didactic communication, so extremely depicted, should not function in any education system. However, one should bear in mind the fact that a teacher with a typical, more defined style is very rarely used in school practice. Most often it is a mix of many features that make up two styles, eg instrumental-allocentric or instrumentalegocentric (Muszkieta 2004, 2005).

\section{Objective of the work}

The aim of the study was to determine the relationship between selected components and the assessment of student achievement represented by the studied physical education teachers teaching communication styles.

\section{Material and methods}

The study involved physical education teachers (women $-\mathrm{N}=282$, men $-\mathrm{N}=298$ ) with full professional qualifications working in primary, middle and secondary schools in Poznan $(\mathrm{N}=204)$, Wroclaw $(\mathrm{N}=171)$ and Lodz $(\mathrm{N}=205)$. A total of 580 teachers.

The average age of respondents was about 35 years, the average age of women was higher and amounted to 36.4 and men 33.3 years. The highest percentage of teachers were aged 31-45 years (49.5\% of all respondents). Analyzing the age range and gender of the surveyed teachers stated that in the age range, ie. $22-30$ years, $29.1 \%$ of women tested and $47.7 \%$ of men in the second range, ie. At the age of $31-45$ years $-54.3 \%$ of women and $45 \%$ of men in the third compartment, ie. over 46 years of age $16.7 \%$ of women and $7.3 \%$ of men. In individual cities (Poznan, Wroclaw and Lodz) age distribution of respondents was similar.

The vast majority of respondents, ie. $88.8 \%$ are graduates of the academy of physical education. The remaining $11.2 \%$ were teachers who have completed other higher education institutions (eg. Universities), 3-year undergraduate teacher training colleges and two-year vocational studies teacher. Approximately $2 / 3$ of respondents graduated from universities in the stationary mode, and only $1 / 3$ in absentia. Master higher education characterized by $97.2 \%$ of women and $94.6 \%$ of men (95.9\% of all respondents). The best educated were teachers from Lodz $98 \%$ of respondents had a higher education degree programs. About $4 \%$ of the respondents had higher vocational education - bachelor. The average seniority of teachers surveyed was 11.4 years. Women characterized by a slightly greater seniority (12.8 years) than men surveyed $(10.1 \%)$.

The study was conducted using a diagnostic survey and research technique was the questionnaire developed by the author of the work and a questionnaire specifying the communication style of teaching Swietochowski (1994).

Statistical analysis. The data were analyzed using the statistical program Statistica 13.0 PL (StatSoft, Poland). The value of the analyzed parameters measured is shown using the value of the mean and standard deviation, and for non-measurable using counts and percentage. The data were subjected to statistical analysis using the independence test Chi square. The strength of the relationship between the test variable was calculated using Cramer's coefficient. Analysis was carried out by significance level $p<0.05$ (probability 95\%). 


\section{Analysis of the test results}

The value assessment of school performance is affected by the characteristics and predispositions of each student.

\section{[Table 1]}

A significant relationship was only found between taking into account the emotional predispositions and teaching styles of communication in the assessment (Table 1). Teachers characterized by the allocentric style more often systematically take into account the emotional predispositions of students in assessing their achievements (44.2\%). Teachers presenting the instrumental and egocentric style sometimes take into account emotional characteristics of students by evaluating their achievements (46\% - instrumental, $44 \%$ - self-centered). Only $15.2 \%$ of teachers with instrumental style, and $26.9 \%$ distributionists and $28 \%$ of egocentrics do not take into account the emotional predispositions of students in the assessment.

The most frequently surveyed teachers, regardless of the didactic communication style presented, take into account the physical predisposition (Yes: 94.2\% - allocentric, 90\% - egocentric, $91.8 \%$ - instrumental) and motor skills (Yes: 86.5\% - allocentric; 76\% - egocentric; 87\% instrumental) of students assessing their work, to a lesser extent mental traits (Yes: $32.7 \%$ allocentric, 38\% - self-centered, 38.6\% - instrumental) Sometimes: 50\% - allocentric; 46\% egocentric, 51.1\% - instrumental) and intellectual (Yes: 44.2\% - allocentric, 42\% - self-centered, $36.4 \%$ - instrumental. Sometimes: $30.8 \%$ - allocentric; $32 \%$ - self-centered, $41 \%$ - instrumental).

\section{[Table 2]}

Analyzing the data contained in Table 2, there were significant relationships between familiarizing students with the criteria of control and evaluation of physical education by the examined teachers and the presented style of didactic communication. However, there is no influence of the teacher's style of communication on the choice of how to familiarize students with the assessment criteria. Egocentric teachers more often do not introduce students to the criteria (4\%) or do so only sometimes $(16 \%)$ than allocentrycs and moderates.

All surveyed teachers commonly use verbal (48.1\% - allocentric, 54\% - egocentric, $50.8 \%$ instrumental) and verbal-written (44.2\% - allocentric, 40\% - self-centered, $43.9 \%$ - instrumental) familiarizing students with the criteria of assessment from physical education (Table 2).

\section{[Table 3]}

Putting the grades at the end of the semester and at the end of the semester depends on the didactic communication style of the teachers being examined (Table 3). No such dependence was found regarding the insufficient rating. Teachers presenting the instrumental style (moderate) more often than allo- and egocentrics score excellent marks during the semester (yes - 82.7\%) and at the end of the school year or semester (yes - 75.3\%).

\section{[Table 4]}

The relationships between equipping students with the skills of self-assessment and selfcontrol of achievements in physical education and the styles of didactic communication in the surveyed teachers are statistically significant. The smallest percentage of surveyed teachers characterized by the egocentric style equips students with the skills of self-assessment and selfcontrol (Often - 22\%), while the highest percentage sometimes accomplishes this task (46\%) or 
does not do it at all (8\%). $34.6 \%$ of allotentric teachers, $24 \%$ self-centered and $23.9 \%$ instrumental apply self-assessment and self-control only in selected educational departments (Table 4).

\section{[Table 5]}

The style of didactic communication occurring in the examined teachers has a significant impact on the use of self-assessment and self-control of students in the areas of movement skills, messages and attitudes and behaviors. This influence on self-esteem and self-control of physical fitness and physical development of students was not observed. Teachers representing the instrumental style more often than the allocentric and egocentric teachers apply self-assessment and self-control among students in the department of motor skills (Yes: 48.1\% - allocentric, 42\% - selfcentered, 66.5\% - instrumental), messages (Yes: 19, 2\% - allocentric, 16\% - egocentric, 28.5\% instrumental) and attitudes and behaviors (Yes: 40.4\% - allocentric, 44\% - self-centered, 51.6\% instrumental). At the same time, the highest percentage of surveyed teachers characterized by egocentric style were found, who did not implement self-assessment and student self-control in the area of motor skills (18\%), messages (42\%), physical development (42\%) and student attitudes $(30 \%)$. The use of self-assessment and self-control by students in physical education lessons conducted by the surveyed teachers is not satisfactory (Table 5).

\section{[Table 6]}

Taking into account the self-esteem of students by the surveyed teachers in determining the semester (annual) assessment is significantly dependent on the style of communication. Assocentric persons undergo suggestion and influence of other people. In this case, we are dealing completely with a different educational situation, because the allocentrists most often out of the surveyed do not take into account the self-assessment of students in the final grade (13.5\%), they do so rarely (13.5\%). Only $1.9 \%$ of allocentrists definitely takes into account student ratings, $32.7 \%$ commonly implements this didactic and educational assumption, and $38.5 \%$ sometimes use the principle of taking into account students' proposals when determining the end-of-term or final year evaluation. Instrumental style teachers show attitudes more involved in cooperation with students when issuing final grades (Table 6).

\section{[Table 7]}

The opinion of the surveyed teachers on the subject of changes in the system and ways of assessing at school after the implementation of the education reform is to a significant extent dependent on the style of didactic communication. Teachers of moderate (instrumental) style expressed a more positive opinion (yes $-20.2 \%$, not at all $-5.3 \%$ ) about changes that took place in the assessment, than egocentric teachers (yes - 16\%, not at all - 8\%) and self-centered (yes - 9.6\%, not at all $-5.8 \%)$. At the same time, the least-studied moderate teachers $(39.1 \%)$ considered that in the future there will be better and more favorable educational changes. The most for the future, or actually for the changes to take place in the assessment, were $54 \%$ of egocentric and $50 \%$ allocentric teachers (Table 7).

\section{[Table 8]}

Relations between the teachers' opinion on control-evaluation activities as the most difficult teaching activities in the education and upbringing process and the didactic communication styles of the teachers surveyed are statistically significant. Most often, as many as $67.4 \%$ of the surveyed teacher of allocentrists stated that control-evaluation activities belong to the most difficult teacher activities (definitely yes $-21.2 \%$, rather yes $-46.2 \%$ ). A similar opinion was expressed by $59.4 \%$ (definitely yes $-18.4 \%$, rather yes $-41 \%$ ) of teachers with instrumental style and $58 \%$ (definitely 
yes $-32 \%$, rather yes $-26 \%$ ) of egocentric teachers. $23.1 \%$ (rather not $-10.6 \%$, not $-12.5 \%$ ) of moderate teachers, $22 \%$ (rather not - 14\%, not - 8\%) egocentric teachers and only 13.4 disagreed with such a statement. $\%$ (probably not $-3.8 \%$, not $-9.6 \%$ ) of allocentrists (Table 8 ).

\section{[Table 9]}

Significant correlation occurring between self-assessment of the performance of inspection and teacher-evaluation and communication styles in the educational subjects (p. Tab.9). The lowest of the respondents assessed their own inspection and evaluation-style allocentric representing teachers (average - 28.8\%; low - 1.9\%, very low - 1.9\%). Only 67.3\% of the abovementioned teachers recognized the performance of procedures for assessing good. Teachers and self-centered very similarly tagged moderate level of their own ability to control and evaluation in three categories: very good (10\% - egocentric, 9\% - instrumental), a well (72\% - egocentric; $76.1 \%$ instrumental) and average (18\% - egocentric; $14.9 \%$ - instrumental).

\section{Summary and Conclusions}

Evaluation of the process of teaching physical education classes was and is the subject of much discussion and research. She did not have an impact on the transformation of the sociopolitical system, initiated in Poland in 1989 and the introduction of a series of reforms in the area of the politico-institutional and social change. The teachers are mostly focused on procedural requirements, and not in the area of teaching and education, which are often underestimated by teachers. This is confirmed by research conducted by teachers Appelt. Analysis of variance shows that the surveyed teachers are people adapting generally passively, reactively adapt to any requirements and people reluctant to any changes (Appelt 2005).

The question arises whether, concentrating on new formal requirements, they want to reflect on didactic activities in this student's assessment.

When assessing physical education, student-teacher communication may be of great importance. Students represent different communication styles (as well as teachers). Pankiewicz (2007) took on the role and importance of communicating talented students. She examined 56 high school students and found that the style of communication was strong, in which the dimension of caring and the tendency of domination were marked. The subjects strive to create nice relationships with others but also give value to others. The results of the research have created (...) a profile whose appearance allows you to think optimistically about the communication skills of gifted students (Pankiewicz 2007, p. 44).

There are difficulties in assessing the students who avoid physical education classes, and the main cause of sick leave are not only relief granted at the request of the students, their parents and themselves. Such test results came Woynarowska conducting surveys in randomly selected group of students aged 10-17 years $(n=3346)$ of 12 provinces (Woynarowska, Mazur, Oblacińska 2015).

An interesting solution for the student's control and assessment with the use of modern technologies in the physical education process is proposed by Dobosz. The use of applications on mobile devices is a way of functioning of young people in the modern world and this allows you to register and analyze student's physical activity. The drummer asks: What, then, stands in the way of including these elements in the arsenal of physical education resources? (Dobosz 2015, p. 202). This type of activity can be found in the "Physical Education with clacc" Program run by the Center for Citizenship Education. The use of new resources, very motivating for young people, to assess a student from physical education is included in the "Active not only online" project implemented by the University of Physical Education in Poznań. All students who take part in the project have been equipped with energy expenditure monitoring devices and control of health self-assessment. The use of modern technologies that inhibits physical activity may lead to the fact that computer games, multimedia, social networks will become an inspiration, medium and means of shaping pro-health attitudes. Using modern technological means, the contact between the teacher and the student can be closer and the student's assessment is more adequate. 
Teachers' assessment of students is inseparable from the teaching process. Analyzing the assessment criteria from 1950 to 2007 Gutowska-Wyrzykowska (2009) lists physical fitness, physical skills, attitude to the subject and knowledge in the field of physical culture. The author asks questions about what to rate: attitudes, messages, practical skills, attendance, progress in fitness, activities for the school or participation in extracurricular activities?

Czerska (2008) notes that the assessment of physical education should take into account the observable changes in the student's personality, both in the physical and intellectual, emotional and social spheres. Noteworthy is the rate of biological development of the ward and his interests and predispositions.

Teachers' views on the assessment of physical education are heading towards a more subjective and humanistic one. Żołyński (2011, p. 239) sees the problem of evaluation aimed at physical education. Analyzing the statements of 396 primary school and 269 junior high school students, respondents believe that a perfect grade should be possible for all students, not just school representatives. The respondents believe that should be taken into account: compulsory, active participation in classes, exemplary behavior in a broad sense, systematic participation in the lesson, proper execution of orders, and other manifestations of the broadly understood attitude.

Assessing student achievement is the culmination of the teaching and learning process, the last stage of it, and at the same time the weakest link in the process. Many teachers, including physical education, evaluate the student very instrumentally, superficially and incorrectly, forgetting about goals, tasks and functions of evaluation, and above all about applying the principle of individualization. Many different factors and components influence the assessment method, including the teacher's didactic communication style represented. It is assumed that the most objective, fair, reliable and "pedagogic" teachers will be characterized by moderate (instrumental) style. In many of the research results discussed, this was how it was shaped, but sometimes allocentric and even egocentric teachers dominated in some elements.

On the basis of the analysis of the research results, the following generalizations and conclusions were developed:

1. Teachers, regardless of the subject represented and the style of communication, should take into account emotional, intellectual and physical predispositions in assessing students' achievements. The surveyed physical education teachers mainly take into account physical predispositions, unfortunately they are much less likely to take into account in assessing the emotional and intellectual state of pupils.

2. Egocentric teachers less often than the allocentric and moderate teachers (instrumental style) apply and implement students to self-assessment and self-control of their own achievements in physical education. Self-assessment and self-control are educational tasks not widely disseminated in the work of physical education teachers of primary, middle and high schools.

3. Student's self-evaluation - sporadically used in the teaching and learning process, is even more rarely taken into account by physical education teachers in determining the final mark of the semester or school year.

4. Moderate teachers (instrumental style) positively assess the assumptions of the Polish reform of the education system in terms of control and assessment than egocentric and allocentric, who predict that only in the future there will be visible and beneficial changes.

\section{Declarations}

\section{Ethics approval and consent to participate}

The research related to human use complied with all the relevant national regulations, institutional policies, and was in accordance with the tenets of the Helsinki Declaration. During realization of tests, all participants provided informed consent and used all measures for maintaining anonymity of participants. 


\section{Consent to publish}

Not applicable

\section{Competing interests}

The authors declare that they have no competing interests.

\section{Funding}

No funding

\section{Authors' contributions}

$\mathrm{RM}, \mathrm{MN}, \mathrm{WZ}$ participated in the design of this study.RM performed the statistical analyses. RM, $\mathrm{MN}, \mathrm{WZ}, \mathrm{MC}, \mathrm{SI}, \mathrm{ZK}$ drafted the manuscript. MC, SI, ZK were involved in data collection and/or made important intellectual contributions to the interpretation of data and the writing of paper. All authors RM, MN, WZ, MC, SI, ZK critically revised and approved the final version.

\section{Acknowledgements}

Not applicable 


\section{References}

Abzalilov, R.Y., Rybakov, V.V., Isaev, A.P., \& Erlikh, V.V. (2017). Adaptation of junior orienteers to loads, developing local-regional and special muscular endurance. Pedagogics, Psychology, Medical-Biological Problems of Physical Training and Sports, 21(5), 200-206. doi:10.15561/18189172.2017.0501.

Appelt K. (2005). Style funkcjonowania nauczycieli $w$ sytuacji zmiany społecznej, Forum Oświatowe, 2(33). s. 1-21, PL ISSN 0867 -0323.

Bodnar, I.R., \& Andres, A.S. (2016). Tests and standards for express-control of physical fitness and health of middle school age pupils. Pedagogics, Psychology, Medical-Biological Problems of Physical Training and Sports, 20(4), 11-16. doi:10.15561/18189172.2016.0402.

Czerska E. (2008). Przedmiotowy system oceniania z wychowania fizycznego, Wychowanie Fizyczne i Zdrowotne, $\mathrm{Nr} 7$.

Dobosz J. (2015). Wykorzystanie technologii informatycznych $w$ procesie edukacji fizycznej, [w]: Wychowanie fizyczne a nowoczesne technologie, (red.) M. Bronikowski AWF Poznań, s. 197-207.

Gutkowska-Wyrzykowska E. (2009). Problematyka oceny szkolnej z wychowania fizycznego w czasopismach polskich z lat 1950-1990, Wychowanie Fizyczne i Zdrowotne, Nr 2.

Koryahin, V.M., \& Blavt, O. Z. (2016). Echnological provisioning of test control of special health group students' power abilities. Physical Education of Students, 20(1), 43-48. doi:10.15561/20755279.2016.0106.

Muszkieta R. (2004). Ocenianie osiagnięć uczniów przez nauczycieli wychowania fizycznego. Poznań.

Muszkieta R. (2005). Physical education teacher - evaluation of students' performance. Wydawnictwo WIGO, Poznań.

Niemierko B. (1997). Między ocena szkolna a dydaktyką. Bliżej dydaktyki. Wydawnictwa Szkolne i Pedagogiczne, Warszawa.

Niemierko B. (1999). Pomiar wyników kształcenia. Wydawnictwa Szkolne i Pedagogiczne, Warszawa.

Osiński W. (1994). Ocena z wychowania fizycznego. Wychowanie Fizyczne i Zdrowotne, Nr 4.

Strzyżewski S. (1996). Proces kształcenia $i$ wychowania $w$ kulturze fizycznej. Wydawnictwa Szkolne i Pedagogiczne, Warszawa.

Pankiewicz M. (2007). Style komunikacji a preferencje wartości uczniów zdolnych, Studia z psychologii, KUL, Tom 14, s. 39-56.

Świętochowski W. (1994). Psychologiczne uwarunkowania stylu komunikowania się. Psychologia Wychowawcza, Nr 3, s.216-223.

Woynarowska B., Mazur J., Oblacińska A. (2015). Uczestnictwo uczniów w lekcjach wychowania fizycznego $w$ szkołach $w$ Polsce, (Participation of students in physical education lessons in schools in Poland), Hygeia Public Health, 50 (1) s. 183-190.

Zerf, Mohammed (2017). Body composition versus body fat percentage as predictors of posture/balance control mobility and stability among football players under 21 years. Physical Education of Students, 21(2), 96-102. doi:10.15561/20755279.2017.0208. 
Table 1. Relationships setting between taking into account the pupils' and features predisposition near estimating their achievements and styles of didactic communication at studied teachers [\%]

\begin{tabular}{|c|c|c|c|c|c|c|c|c|c|c|c|c|c|c|c|c|}
\hline \multirow{3}{*}{$\begin{array}{l}\text { The styles of } \\
\text { communicating }\end{array}$} & \multirow[t]{3}{*}{$\mathrm{N}$} & \multicolumn{15}{|c|}{ Taking into account in estimating pupils' predisposition } \\
\hline & & \multicolumn{3}{|c|}{ Physical } & \multicolumn{3}{|c|}{ Psychical } & \multicolumn{3}{|c|}{ Emotional } & \multicolumn{3}{|c|}{ Intellectual } & \multicolumn{3}{|c|}{ Motor } \\
\hline & & 1 & 2 & 3 & 1 & 2 & 3 & 1 & 2 & 3 & 1 & 2 & 3 & 1 & 2 & 3 \\
\hline Allocentric & 104 & 94,2 & 5,8 & 0 & 32,7 & 50,0 & 17,3 & 44,2 & 28,8 & 26,9 & 44,2 & 30,8 & 25,0 & 86,5 & 9,6 & 3,8 \\
\hline Egocentric & 100 & 90,0 & 10,0 & 0 & 38,0 & 46,0 & 16,0 & 28,0 & 44,0 & 28,0 & 42,0 & 32,0 & 26,0 & 76,0 & 18,0 & 6,0 \\
\hline Instrumental & 376 & 91,8 & 6,4 & 1,9 & 38,6 & 51,1 & 10,4 & 38,8 & 46,0 & 15,2 & 36,4 & 41,0 & 22,6 & 87,0 & 8,5 & 4,5 \\
\hline \multicolumn{2}{|c|}{ Test $\mathrm{Chi}^{\wedge} 2$} & \multicolumn{3}{|c|}{$\begin{array}{c}\chi^{2}=5,63 \\
\text { VCramer }=0,070\end{array}$} & \multicolumn{3}{|c|}{$\begin{array}{c}\chi^{2}=5,40 \\
\text { VCramer }=0,068\end{array}$} & \multicolumn{3}{|c|}{$\begin{array}{c}\chi^{2}=19,75^{* *} \\
\text { VCramer }=0,131\end{array}$} & \multicolumn{3}{|c|}{$\begin{array}{c}\chi^{2}=5,34 \\
\text { VCramer }=0,068\end{array}$} & \multicolumn{3}{|c|}{$\begin{array}{c}\chi^{2}=8,64 \\
\text { VCramer }=0,086\end{array}$} \\
\hline
\end{tabular}

The legend: Taking into account in estimating pupils' predisposition: 1 - YES; 2 - OCCASIONALLY; 3 - NO.

Table 2. Relationships setting between acquainting with criterions of control and opinion the pupils with physical education and styles of didactic communication at studied teachers [\%]

\begin{tabular}{|c|c|c|c|c|c|c|c|c|}
\hline \multirow[t]{2}{*}{$\begin{array}{l}\text { The styles of } \\
\text { communicating }\end{array}$} & \multirow[t]{2}{*}{$\mathrm{N}$} & \multicolumn{3}{|c|}{$\begin{array}{l}\text { Acquainting with criterions of } \\
\text { control the pupils of } P E\end{array}$} & \multicolumn{4}{|c|}{$\begin{array}{l}\text { The ways of acquainting with criterions of } \\
\text { control the pupils of } P E\end{array}$} \\
\hline & & Yes & Occasionally & No & Say & In writing & Both ways & Different \\
\hline Allocentric & 104 & 96,2 & 3,8 & 0 & 48,1 & 5,8 & 44,2 & 1,9 \\
\hline Egocentric & 100 & 80,0 & 16,0 & 4,0 & 54,0 & 2,0 & 40,0 & 4,0 \\
\hline Instrumental & 376 & 92,6 & 5,3 & 2,1 & 50,8 & 2,1 & 43,9 & 3,2 \\
\hline \multicolumn{2}{|l|}{ Test $\mathrm{Chi}^{\wedge}{ }^{\wedge}$} & \multicolumn{3}{|c|}{$\mathrm{V}_{\text {Cramer }}=0,133$} & \multicolumn{4}{|c|}{$\chi^{2}=5,56$} \\
\hline
\end{tabular}

Table 3. Relationships setting between the takli stringing the bad mark and excellent in track the duration of semester and to the end the semester and the styles of didactic communication at studied teachers [\%]

\begin{tabular}{|c|c|c|c|c|c|c|c|c|c|c|c|c|c|}
\hline \multirow{4}{*}{$\begin{array}{l}\text { The styles of } \\
\text { communicating }\end{array}$} & \multirow[t]{4}{*}{$\mathrm{N}$} & \multicolumn{12}{|c|}{ To give marks } \\
\hline & & \multicolumn{6}{|c|}{ In track the duration of semester } & \multicolumn{6}{|c|}{ The end the semester } \\
\hline & & \multicolumn{3}{|c|}{ The bad marks } & \multicolumn{3}{|c|}{ Excellent } & \multicolumn{3}{|c|}{ The bad marks } & \multicolumn{3}{|c|}{ Excellent } \\
\hline & & Yes & Time & No & Yes & Time & No & Yes & Time & No & Yes & Time & No \\
\hline Allocentric & 104 & 48,1 & 23,1 & 28,8 & 65,4 & 26,9 & 7,7 & 5,8 & 13,5 & 80,8 & 48,1 & 46,2 & 5,8 \\
\hline Egocentric & 100 & 52,0 & 16,0 & 32,0 & 72,0 & 20,0 & 8,0 & 12,0 & 10,0 & 78,0 & 58,0 & 30,0 & 12,0 \\
\hline Instrumental & 376 & 57,4 & 14,6 & 27,9 & 82,7 & 7,4 & 9,8 & 14,4 & 6,9 & 78,7 & 75,3 & 19,7 & 5,1 \\
\hline \multicolumn{2}{|c|}{ Test $\mathrm{Chi}^{\wedge} 2$} & \multicolumn{3}{|c|}{$\begin{array}{c}\chi^{2}=5,5 \\
\text { V Cramer }=0,069\end{array}$} & \multicolumn{3}{|c|}{$\begin{array}{c}\chi^{2}=32,21 * * \\
V \text { Cramer }=0,167\end{array}$} & \multicolumn{3}{|c|}{$\begin{array}{c}\chi^{2}=9,24 \\
\text { V Cramer }=0,089\end{array}$} & \multicolumn{3}{|c|}{$\begin{array}{c}\chi^{2}=39,02^{* *} \\
\mathrm{~V} \text { Cramer }=0,183\end{array}$} \\
\hline
\end{tabular}

Table 4. Relationships setting between providing in skill of self-control of achievements the pupils with physical education and styles of didactic communication at studied teachers [\%]

\begin{tabular}{|c|c|c|c|c|c|}
\hline $\begin{array}{c}\text { The styles of } \\
\text { communicating }\end{array}$ & \multirow{N}{*}{} & \multicolumn{4}{|c|}{ Teaching of self-control the pupils of PE } \\
\cline { 3 - 6 } & & Often & Occasionally & The chosen disciplines & At all \\
\hline Allocentric & 104 & 34,6 & 28,8 & 34,6 & 1,9 \\
\hline Egocentric & 100 & 22,0 & 46,0 & 24,0 & 8,0 \\
\hline Instrumental & 376 & 32,4 & 39,4 & 23,9 & 4,3 \\
\hline \multicolumn{2}{|c|}{ Test Chi^2 } & \multicolumn{5}{|c|}{$\chi^{2}=15,42^{*} *$ Cramer $=0,115$} \\
\hline
\end{tabular}


Table 5. Relationships setting between usage by pupils the self-control of achievements with physical education and styles of didactic communication at studied teachers [\%]

\begin{tabular}{|c|c|c|c|c|c|c|c|c|c|c|c|c|c|c|c|c|}
\hline \multirow{3}{*}{$\begin{array}{l}\text { The styles of } \\
\text { communicating }\end{array}$} & \multirow[t]{3}{*}{$\mathrm{N}$} & \multicolumn{15}{|c|}{ Usage by pupils the self-control of PE } \\
\hline & & \multicolumn{3}{|c|}{ Fitness } & \multicolumn{3}{|c|}{$\begin{array}{l}\text { Competence } \\
\text { movement }\end{array}$} & \multicolumn{3}{|c|}{ Learning } & \multicolumn{3}{|c|}{$\begin{array}{l}\text { Physical } \\
\text { progress }\end{array}$} & \multicolumn{3}{|c|}{ Attitude } \\
\hline & & 1 & 2 & 3 & 1 & 2 & 3 & 1 & 2 & 3 & 1 & 2 & 3 & 1 & 2 & 3 \\
\hline Allocentric & 104 & 53,8 & 19,2 & 26,9 & 48,1 & 17,3 & 34,6 & 19,2 & 38,5 & 42,3 & 32,7 & 32,7 & 34,6 & 40,4 & 19,2 & 40,4 \\
\hline Egocentric & 100 & 60,0 & 16,0 & 24,0 & 42,0 & 18,0 & 40,0 & 16,0 & 42,0 & 42,0 & 22,0 & 42,0 & 36,0 & 44,0 & 30,0 & 26,0 \\
\hline Instrumental & 376 & 64,4 & 9,6 & 26,1 & 66,5 & 9,6 & 23,9 & 28,5 & 26,3 & 45,2 & 31,4 & 30,9 & 37,8 & 51,6 & 12,8 & 35,6 \\
\hline \multicolumn{2}{|c|}{ Test $\mathrm{Chi}^{\wedge} 2$} & \multicolumn{3}{|c|}{$\begin{array}{c}\chi^{2}=9,07 \\
\text { VCramer }=0,088\end{array}$} & \multicolumn{3}{|c|}{$\begin{array}{c}\chi^{2}=26,26 * * \\
\text { VCramer }=0,151\end{array}$} & \multicolumn{3}{|c|}{$\begin{array}{c}\chi^{2}=15,12^{* *} \\
\text { VCramer }=0,114\end{array}$} & \multicolumn{3}{|c|}{$\begin{array}{c}\chi^{2}=5,84 \\
\text { VCramer }=0,071\end{array}$} & \multicolumn{3}{|c|}{$\begin{array}{c}\chi^{2}=20,10^{* *} \\
\text { VCramer }=0,132\end{array}$} \\
\hline
\end{tabular}

The legend: Usage by pupils of self-control: 1-YES; 2-NO; 3-OCCASIONALLY

Table 6. Relationships setting between taking into account the pupil's of self-control near set the semestral opinion and the styles of didactic communication at studied teachers [\%]

\begin{tabular}{|c|c|c|c|c|c|c|}
\hline \multirow{2}{*}{$\begin{array}{l}\text { The styles of } \\
\text { communicating }\end{array}$} & \multirow{2}{*}{$\mathrm{N}$} & \multicolumn{5}{|c|}{ Taking into account the pupil's of self-control near set the semestral opinion } \\
\hline & & Decidedly so & Yes & Occasionally & Rarely & No \\
\hline Allocentric & 104 & 1,9 & 32,7 & 38,5 & 13,5 & 13,5 \\
\hline Egocentric & 100 & 0 & 38,0 & 46,0 & 10,0 & 6,0 \\
\hline Instrumental & 376 & 6,4 & 42,8 & 32,7 & 11,7 & 6,4 \\
\hline \multicolumn{2}{|c|}{ Test $\mathrm{Chi}^{\wedge} 2$} & \multicolumn{5}{|c|}{$\chi^{2}=21,63^{* *}$} \\
\hline
\end{tabular}

Table 7. Relationships setting between teachers' opinion "the positive changes in system and way estimating at Polish school" and the styles of didactic communication at studied teachers [\%]

\begin{tabular}{|c|c|c|c|c|c|c|}
\hline \multirow{2}{*}{$\begin{array}{c}\text { The styles of } \\
\text { communicating }\end{array}$} & \multirow{2}{*}{$\mathrm{N}$} & \multicolumn{5}{|c|}{ The introduced reform of education in Polsce altered the system and prepare the } \\
estimating at school the pupil?
\end{tabular}

Table 8. Relationships setting between teachers' opinion "the action control - estimating as the most difficult the teacher's actions in process education" and the styles of didactic communication at studied teachers [\%]

\begin{tabular}{|c|c|c|c|c|c|c|c|}
\hline $\begin{array}{c}\text { The styles of } \\
\text { communicating }\end{array}$ & $\mathrm{N}$ & \multicolumn{6}{|l|}{ Is the controlment and estimating once of the teacher's the most difficult actions } \\
in process the education? \\
\end{tabular}


Table 9. Relationships setting between the teachers' of self-control of exercise of action control - estimating the and styles of didactic communication at studied teachers [\%]

\begin{tabular}{|c|c|c|c|c|c|c|}
\hline \multirow{2}{*}{$\begin{array}{c}\text { The styles of } \\
\text { communicating }\end{array}$} & \multirow{2}{*}{$\mathrm{N}$} & \multicolumn{2}{|c|}{ The teachers' of self-control of exercise of action control - estimating } \\
\cline { 3 - 7 } & & Very good & Good & On an average & Weakly & Very weakly \\
\hline Allocentric & 104 & 0 & 67,3 & 28,8 & 1,9 & 1,9 \\
\hline Egocentric & 100 & 10,0 & 72,0 & 18,0 & 0 & 0 \\
\hline Instrumental & 376 & 9,0 & 76,1 & 14,9 & 0 & 0 \\
\hline Test $\mathrm{Chi}^{\wedge} 2$ & \multicolumn{7}{|c|}{$\chi^{2}=37,76^{* *}$ V Cramer $=0,180$} \\
\hline
\end{tabular}

